\title{
A Study on Economics Analysis of Diversification Farming System in Satpura Plateau Region of Madhya Pradesh, India
}

\author{
Sangeeta Mawase ${ }^{1}$, Sunil Kumar Mawase ${ }^{2^{*}}$, Anil Kumar Rai ${ }^{3}$ and Jitendra Patidar \\ ${ }^{1}$ Department of Agricultural Economics and farm management, J.N.K.V.V. Jabalpur, \\ Madhya Pradesh, India \\ ${ }^{2}$ Faculty of Science of Environment, M.G.C.G, V.V. Chitrakoot Satna, Madhya Pradesh, India \\ ${ }^{3}$ Department of Agronomy, R.V.S.K.V.V. Gwalior, Madhya Pradesh, India \\ ${ }^{4}$ Department of Agronomy, J.N.K.V.V. Jabalpur, Madhya Pradesh, India \\ *Corresponding author
}

\section{Keywords \\ Diversification, \\ Estimation, \\ Profitability, \\ Proportionate, \\ Farming system}

Article Info

Accepted:

20 January 2018

Available Online:

10 February 2018

\section{A B S T R A C T}

The research study entitled "A study on Economics Analysis of Diversification Farming System in Satpura Plateau Region of Madhya Pradesh" has been undertaken to study the location-specific exiting farming system along with their profitability and extent of diversification in the Satpura Plateau Region of Madhya Pradesh. Satpura plateau region of Madhya Pradesh was considered for study purpose. Satpura Plateau Region covers two districts i.e. Chhindwara and Betul. Chhindwara district having 11 blocks and Betul district having 10 blocks. One block from each district (i.e. Chhindwara and Multai) was selected purposively on the basis of more coverage of Agricultural Crops, Horticulture and dairy enterprises. After selection of block, lists of villages were prepared and then five villages were selected from each selected block. The list of farmer those who raised the Agricultural Crops, Horticulture and dairy enterprises were prepared and further categories into three groups on the basis of size of land holdings i.e. small (up to $2.0 \mathrm{ha}$ ) medium ( 2.1 to $4.0 \mathrm{ha}$ ) and large (above $4.0 \mathrm{ha}$ ) from each size group. Total 42 farmers were considered for detail investigation to fulfill. For the collection of primary data survey method was adopted to conduct the inquiry by personal visit with the help of interview schedule. The estimation of cost and return of different crops, scientific cost concepts were used. The result shows that on an average selling market price of milk (per liter) was observed to be Rs. 25 for all the size groups in dairy enterprise system. On an average of Rs. 126.54 income per day per animal was received from milk, F.Y.M. and dung under dairy enterprise system. More than 95 per cent income received from milk in all the size groups. The maximum gross income was obtained from Cabbage followed by Maize, Wheat, Paddy, Soybean, Marigold and Gram. It was found to be Rs. 82575, 77869, 96785, 69916, 66035, 42560 and 163500 for Paddy, Maize, Soybean, Wheat, Gram, Marigold and Cabbage respectively. The variation in gross income in different crops was observed in all the size groups due to price and level of production of different crops in the study area. Under crop group, the average net, farm business, and family labour income per hectare were observed to be Rs. 43405, 63879 and 49494 respectively. The gross income was found to be Rs. 79425, 77187, 95745, 70750, 65586, 41880 and 160000 for Paddy, Maize, Soybean, Wheat, Gram, Marigold and Cabbage respectively. The average net farm income per hectare was observed to be Rs. 46795,47882 and 46017 for small, medium and large size group respectively. Dairy enterprise was also found profitable enterprise in the farming system. On an average net profit per annum of dairy were observed to be Rs. 42931,44490 and 39780 under small, medium and large size group respectively. It could be concluded that farmers of different size groups i.e. small, medium and large adopted farming system which included three components i.e. crop, horticulture and dairy enterprise and this farming system was shows profitable business in the study area. It is revealed that on an average net profit was observed to be under different size groups of farming system, the highest net profit was received from horticulture then other components. It was found Rs. 41816, Rs. 51980 and Rs. 42400 for crop, horticulture and dairy per annum respectively. Over all it could be concluded that the highest net income was received from diversification farming system. Among the diversification farming system i.e. crop + horticulture + dairy enterprise was found most profitable in the study area. There is ample scope for increasing the farm income if farmers adopted diversification farming system in the study area. In this way more income and employment may be generated and improved the economic condition of farming community. 


\section{Introduction}

Agriculture plays an important role in the economy of Madhya Pradesh as 80 per cent of the total population depends on agriculture. Only 49 per cent of the total geographical area is available for agriculture out of which 43.3 per cent is rain-fed and the holdings are small and scattered. Around 65 per cent of the total land holdings belong to small and marginal farmers occupying only 26 per cent of the cultivated land. Despite all these barring factors, climate of the state, especially in the Satpura Plateau Region is congenial for the cultivation of many vegetables and floricultural crops. Diversification of Agriculture in favour of more competitive and high value enterprises is considered as an important strategy to augment farm income, generate employment, alleviate poverty and conserve precious soil and water resources. High value crops have enormous demand potential in India is reflected by the rapid increase in the consumption of high value food commodities. Indian agriculture is gradually diversifying towards high value crops. So a sound and empirical understanding about the nature of crop diversification in Satpura Plateau Region of Madhya Pradesh and the constraints in accelerating its spread is needed such study would provide a strong support to evolving of appropriate policies for the development of required institutional arrangements and creation of adequate infrastructure for promoting crop diversification in the Satpura Plateau Region. Agricultural diversification is one of the several pathways of agricultural development. The demand for high-value food products such as fruits, vegetables, milk, meat and fish has been increasing rapidly in the domestic, as well as in the global markets. Further, with ongoing process of market liberalization and globalization the domestic as well as global markets are moving towards integration. The state of Madhya Pradesh has a congenial agro- climatic environment favouring cultivation of a variety of seasonal and off-season vegetables, fruits, flowers, spices, and aromatic and medicinal plants. Diversification of agriculture is also adopted as a strategy to minimize risk to lower crop failure where the immediate goal is not to make profit but to stabilize income for survival. Diversification is an age old practice of risk minimization and attainment of stable income from the farm. Farm diversification includes diversification of crops and farm based enterprises to broaden the income base of the farmers, resulting in the increased level of employment, production and income. Dairying being a self-income enterprise is an important alternative to diversify the arable farming for getting more, stable and continuous farm income and higher employment opportunities on smaller farms. However an omnipresent problem facing the farmer these days lies in the decision making about the profitable levels of diversification of crop farming with dairying so as to maximize his farm profits by increasing the productivity of milch animals and crops per unit of land and time with in the frame work scarce resources. The progress in production or steady growth in output is necessary to meet the challenges posed by the present economic, political and technological environment, On the other hand, farmers need to be assured of regular income for living at least above the poverty line. In this context, adoption of farming system approach is one of the important solutions to meet this peculiar situation because in the farming system approach, different enterprises can be under taken meaningfully and based on the available resources, location-specific system can be developed which will result into sustainable agricultural development. In view of this, the research study has been undertaken to studied the location-specific exiting farming system along with their profitability and extent of diversification in the Satpura Plateau Region of Madhya Pradesh. 


\section{Materials and Methods}

The Madhya Pradesh state was divided in to following 11 agro climatic zones viz. Chhattisgarh Plains, Northern Hill Region of Chhattisgarh, Kymore Plateau Satpura Hills, Central Narmada Valley Region, Vindhya Plateau Region, Gird Region, Bundelkhand Region, Satpura Plateau Region, Malwa Plateau, Nimar Plains and Jhabua Hill. In which Satpura plateau region of Madhya Pradesh was consider for study purpose as this region is very potential for productivity of different Agricultural Crops and Horticulture and dairy enterprise. Satpura Plateau Region covers two districts i.e. Chhindwara and Betul. Chhindwara district having 11 blocks viz. Chhindwara, Mohakhed, Chourai, Parasia, Junnardeo, Tamia, Amarwara, Harrai, Sausar, Bichua and Pandhurna. Betul district having 10 blocks viz. Betul, Shahapur, Ghoradongri, Chicholi, Bhimpur, Bhainsdehi, Athner, Amla, Multai, and Prabhat Pattan. One block from each district (i.e. Chhindwara and Multai) was selected purposively on the basis of more coverage of Agricultural Crops, Horticulture and dairy enterprises. After selection of block, a list of villages was prepared and then five villages were selected from each selected block. In Chhindwara block five villages namely Sonepur, Gouraiya, Partala, Rohnkala and Chandangaon, and from Multai block five villages namely Dunai, Jaam, Musakhapa, Dunawa and Samriya Pandri were selected on the basis of same criteria as adopted for selection of block.

The list of farmer those who raised the Agricultural Crops, Horticulture and dairy enterprises were prepared and further categories into three groups on the basis of size of land holdings i.e. small (up to $2.0 \mathrm{ha}$ ) medium (2.1 to 4.0 ha) and large (above 4.0 ha). For selection of 42 farmers i.e. small (17), medium (16) and large (09). Proportionate random sampling techniques were used.
For the collection of primary data survey method was adopted to conduct the inquiry by personal visit with the help of interview schedule. For estimation of cost and return of different crops, scientific cost concepts were used. For estimation of income, three measures viz., Net farm income, Farm business income and Family labour income were used.

\section{Results and Discussion}

\section{Milk production under dairy enterprise}

On an average milk production per animal per day was found 4.93 liter under dairy enterprise system. Average milk production per animal per day was increases as size group increased but the difference among the size groups was marginal. Average selling market price of milk (per liter) was observed to be Rs. 25 for all the size groups in dairy enterprise system. The average market price of milk was found Rs. 25 per liter and it was low then the price of milk in the urban area it may be due to selling the milk at the village level. Details about milk production and its price are given in Table 1.

\section{Income from dairy enterprise system}

In dairy enterprise, milk was the main source of income, but in additions to milk, income also received by the farmers from F.Y.M. and dung in the study area. On an average of Rs. 126.54 income per day per animal was received from milk, F.Y.M. and dung under dairy enterprise system. More than 95 per cent income received from milk in all the size groups. Details about income from dairy enterprise are given in Table 2.

\section{Net profits from dairy enterprise system}

On an average Rs. 77.2 net profit per day per animal was received from dairy enterprise 
system. The average cost of production per liter of milk was estimated to be Rs. 10.0. As far as Benefit cost ratio was concerned, on an average it was 1:2.56 which indicates that dairy enterprise is profitable business. Average annual net profit per dairy farm was estimated Rs. 42401 under dairy enterprise system. Net profits from dairy enterprise system are given in Table 3 .

\section{Estimation of cost of cultivation}

The details about estimated cost of cultivation of selected crop on the basis of cost concept under different size group have been provided in Table 4. In small size group the analysis shows that the total cost of cultivation (cost $\mathrm{C}_{3}$ ) per hectare. Under small size groups came to Rs. 34333 and Rs. 50754 in crop group and horticulture group respectively. The cost $\mathrm{A}_{2}$ represents paid out cost in terms of cash and kind involved in crop production.

Cost $A_{1}$ and $A_{2}$ of sample farmers are the same due to absence of the practice of leasing and therefore cost $A_{1}$ was not mentioned in the table. The percentage of cost $A_{2}$ to cost $C_{3}$ was estimated to be 44.1, 36.4, 38.6, 41.5, 40.8, 45.6 and 39.5 for Paddy, Maze, Soybean, Wheat, Gram, Marigold and Cabbage respectively. It could be concluded that total cost of cultivation per hectare $\left(\operatorname{cost} \mathrm{C}_{3}\right.$ ) was found maximum in Cabbage (Rs. 76850) and minimum (Rs. 30792) in Maize crop. Over all on an average the total cost of cultivation (cost $\mathrm{C}_{3}$ ) was found to be (Rs. 42543) per hectare.
Under medium size group of selected farming system the total cost $\left(\operatorname{cost} \mathrm{C}_{\mathbf{3}}\right)$ of cultivation per hectare of Cabbage was higher (Rs. 76315) than remaining crops. The percentage of cost $A_{2}$ to cost $C_{3}$ was vary under different crops. It was 48.7, 46.7, 51.4, 56.7, 51.2, 50.2 and 51.1 per cent for Paddy, Maize, Soybean, Wheat, Gram, Marigold and Cabbage respectively. It could be concluded that on an average total cost of cultivation per hectare was estimated to be Rs. 38337 and Rs. 51576 for crop and horticulture group. Under the horticulture group, total cost was 27 per cent higher than the crop group which indicates more fund is required for raising horticulture crop.

Large size group of selected farming system the total cost of cultivation $\left(\operatorname{cost} \mathrm{C}_{3}\right.$ ) per hectare of horticulture crop group was 25 per cent higher than the crop group. The percentage of cost $A_{2}$ to Cost $C_{3}$ was vary under different crops. It was observed that 28 per cent more cost is required in horticulture group than the crop group. On an average total cost of cultivation per hectare $\left(\operatorname{cost} \mathrm{C}_{3}\right)$ was Rs. 37789 and Rs. 50816 for crop and horticulture group. Overall average cost of cultivation per hectare was estimated to be Rs. 44302. Thus it could be concluded that pattern of investment on different crops was near about same in all the categories of size groups. The total cost of cultivation $\left(\operatorname{cost} \mathrm{C}_{3}\right.$ ) per hectare of all the selected crops increased with the size of land holding.

Table.1 Milk production under dairy enterprise

\begin{tabular}{|c|c|c|c|c|}
\hline Particulars & Small & Medium & Large & Average \\
\hline Total milk production (liter) & 52433 & 43435 & 20203 & $\mathbf{3 8 6 9 0}$ \\
\hline $\begin{array}{c}\text { Average milk production per animal } \\
\text { per day (liter) }\end{array}$ & 4.94 & 5.05 & 4.80 & $\mathbf{4 . 9 3}$ \\
\hline \begin{tabular}{c} 
Average market Price (Rs. per liter) \\
\hline
\end{tabular} & 25 & 25 & 25 & $\mathbf{2 5}$ \\
\hline
\end{tabular}


Table.2 Income from dairy enterprise system

Unit: Rs. per day per animal

\begin{tabular}{|c|}
\hline Sources \\
\hline Milk \\
\hline F.Y.M. \\
\hline Dung \\
\hline Total \\
\hline
\end{tabular}

\begin{tabular}{|c|}
\hline Small \\
\hline 123.50 \\
\hline 2.47 \\
\hline 0.92 \\
\hline $\mathbf{1 2 6 . 8 9}$ \\
\hline
\end{tabular}

\begin{tabular}{|c|}
\hline Medium \\
\hline 126.25 \\
\hline 2.89 \\
\hline 0.78 \\
\hline $\mathbf{1 2 9 . 9 2}$ \\
\hline
\end{tabular}

\begin{tabular}{|c|c|}
\hline Large & A verage \\
\hline 120.00 & 123.25 \\
\hline 2.12 & 2.49 \\
\hline 0.69 & 0.79 \\
\hline $\mathbf{1 2 2 . 8 1}$ & $\mathbf{1 2 6 . 5 4}$ \\
\hline
\end{tabular}

Table.3 Net profit from dairy enterprise system

Unit: Rs. per day per animal

\begin{tabular}{|c|c|c|c|c|}
\hline Particulars & Small & Medium & Large & Average \\
\hline Gross income & 126.8 & 129.9 & 122.8 & $\mathbf{1 2 6 . 5}$ \\
\hline Gross expenses & 48.6 & 48.8 & 50.3 & $\mathbf{4 9 . 3}$ \\
\hline Net profit & 78.2 & 81.0 & 72.4 & $\mathbf{7 7 . 2}$ \\
\hline Average net profit per annum & 42931 & 44490 & 39780 & $\mathbf{4 2 4 0 1}$ \\
\hline Cost of production per liter of milk & 9.8 & 9.7 & 10.5 & $\mathbf{1 0 . 0}$ \\
\hline Benefit cost ratio & $1: 2.60$ & $1: 2.65$ & $1: 2.43$ & $\mathbf{1 : 2 . 5 6}$ \\
\hline Average no. of milch animal & 3 & 3 & 3 & $\mathbf{3}$ \\
\hline
\end{tabular}

Table.4 Productivity and gross income of selected crops under farming system

\begin{tabular}{|c|c|c|c|c|c|}
\hline \multicolumn{6}{|c|}{ Small size group } \\
\hline Crops & Productivity Qt./ha. & Value & By Product Qt./ ha. & Value & Gross Income \\
\hline Paddy & 42.36 & 76248 & 63.54 & 3177 & 79425 \\
\hline Maize & 46.78 & 70170 & 140.34 & 7017 & 77187 \\
\hline Soybean & 29.46 & 94272 & 29.46 & 1473 & 95745 \\
\hline Wheat & 45.28 & 67920 & 56.60 & 2830 & 70750 \\
\hline Gram & 25.72 & 64300 & 25.72 & 1286 & 65586 \\
\hline Marigold & 27.92 & 41880 & - & - & 41880 \\
\hline Cabbage & 320.0 & 160000 & - & - & 160000 \\
\hline \multicolumn{6}{|c|}{ Medium size group } \\
\hline Paddy & 45.70 & 82260 & 68.55 & 3427 & 85687 \\
\hline Maize & 47.11 & 70665 & 141.33 & 7066 & 77731 \\
\hline Soybean & 28.64 & 91648 & 28.64 & 1432 & 93080 \\
\hline Wheat & 42.54 & 63810 & 53.17 & 2658 & 66468 \\
\hline Gram & 27.69 & 69225 & 27.69 & 1384 & 70609 \\
\hline Marigold & 30.62 & 45930 & - & - & 45930 \\
\hline Cabbage & 336.0 & 168000 & - & - & 168000 \\
\hline \multicolumn{6}{|c|}{ Large size group } \\
\hline Paddy & 44.06 & 79308 & 66.09 & 3304 & 82612 \\
\hline Maize & 47.69 & 71535 & 143.07 & 7153 & 78688 \\
\hline Soybean & 31.24 & 99968 & 31.24 & 1562 & 101530 \\
\hline Wheat & 46.42 & 69630 & 58.02 & 2901 & 72531 \\
\hline Gram & 24.28 & 60700 & 24.28 & 1214 & 61914 \\
\hline Marigold & 26.58 & 39870 & - & - & 39870 \\
\hline Cabbage & 325.0 & 162500 & - & - & 162500 \\
\hline \multicolumn{6}{|c|}{ Over all average } \\
\hline Paddy & 44.04 & 79272 & 66.06 & 3303 & 82575 \\
\hline Maize & 47.19 & 70790 & 141.58 & 7079 & 77869 \\
\hline Soybean & 29.78 & 95296 & 29.78 & 1489 & 96785 \\
\hline Wheat & 44.74 & 67120 & 55.93 & 2796 & 69916 \\
\hline Gram & 25.89 & 64741 & 25.89 & 1294 & 66035 \\
\hline Marigold & 28.37 & 42560 & - & - & 42560 \\
\hline Cabbage & 327.0 & 163500 & - & - & 163500 \\
\hline
\end{tabular}


Table.5 Cost of cultivation of selected crops (cost concept basis) under farming system

Unit : Rs./ha

\begin{tabular}{|c|c|c|c|c|c|c|c|c|c|c|}
\hline \multirow[t]{2}{*}{ Particulars } & \multicolumn{6}{|c|}{ Crops } & \multicolumn{3}{|c|}{ Horticulture } & \multirow{2}{*}{$\begin{array}{l}\text { Over all } \\
\text { average }\end{array}$} \\
\hline & Paddy & Maize & Soybean & Wheat & Gram & Average & Marigold & Cabbage & Average & \\
\hline \multicolumn{11}{|l|}{ Small size group } \\
\hline $\operatorname{Cost} \mathbf{A}_{2}$ & $\begin{array}{l}15937 \\
(44.1)\end{array}$ & $\begin{array}{l}11217 \\
(36.4)\end{array}$ & $\begin{array}{l}15224 \\
(38.6)\end{array}$ & $\begin{array}{l}13544 \\
(41.5)\end{array}$ & $\begin{array}{l}13371 \\
(40.8)\end{array}$ & $\begin{array}{l}13859 \\
(40.3)\end{array}$ & $\begin{array}{l}11262 \\
(45.6)\end{array}$ & $\begin{array}{l}30369 \\
(39.5)\end{array}$ & $\begin{array}{l}20815 \\
(41.0)\end{array}$ & $\begin{array}{l}17337 \\
(40.7)\end{array}$ \\
\hline $\operatorname{Cost} B_{1}$ & 17365 & 12646 & 16653 & 14972 & 14799 & 15287 & 12690 & 31797 & 22243 & 18765 \\
\hline Cost $B_{2}$ & 30602 & 25510 & 32610 & 26764 & 25730 & 28243 & 19670 & 58464 & 39067 & 33655 \\
\hline Cost $C_{1}$ & 19615 & 15128 & 19878 & 17812 & 18844 & 18255 & 15435 & 43197 & 29316 & 23786 \\
\hline Cost $\mathrm{C}_{2}$ & 32852 & 27992 & 35835 & 29604 & 29775 & 31212 & 22415 & 69864 & 46140 & 38676 \\
\hline Cost $\mathrm{C}_{3}$ & 36138 & 30792 & 39419 & 32565 & 32753 & 34333 & 24657 & 76850 & 50754 & 42543 \\
\hline \multicolumn{11}{|l|}{ Medium size group } \\
\hline $\operatorname{Cost} \mathbf{A}_{2}$ & $\begin{array}{l}18702 \\
(48.7)\end{array}$ & $\begin{array}{l}15803 \\
(46.7)\end{array}$ & $\begin{array}{l}22452 \\
(51.4)\end{array}$ & $\begin{array}{l}22953 \\
(56.7)\end{array}$ & $\begin{array}{l}18152 \\
(51.2)\end{array}$ & $\begin{array}{l}19612 \\
(51.1)\end{array}$ & $\begin{array}{l}13482 \\
(50.2)\end{array}$ & $\begin{array}{l}39061 \\
(51.1)\end{array}$ & $\begin{array}{l}26272 \\
(50.9)\end{array}$ & $\begin{array}{l}22942 \\
(51.0)\end{array}$ \\
\hline Cost $B_{1}$ & 20067 & 17167 & 23817 & 24317 & 19517 & 20977 & 14847 & 40425 & 27636 & 24307 \\
\hline Cost $B_{2}$ & 34348 & 30122 & 39330 & 35395 & 31285 & 34096 & 22502 & 68425 & 45464 & 39780 \\
\hline$\overline{C o s t} C_{1}$ & 20592 & 17788 & 24127 & 25706 & 20451 & 21733 & 16743 & 41377 & 29060 & 25396 \\
\hline Cost $C_{2}$ & 34873 & 30743 & 39641 & 36784 & 32219 & 34852 & 24398 & 69377 & 46888 & 40870 \\
\hline Cost $\mathrm{C}_{3}$ & 38360 & 33817 & 43605 & 40462 & 35441 & 38337 & 26838 & 76315 & 51576 & 44957 \\
\hline \multicolumn{11}{|l|}{ Large size group } \\
\hline Cost $\mathbf{A}_{2}$ & $\begin{array}{l}19153 \\
(50.1)\end{array}$ & $\begin{array}{l}16162 \\
(47.3)\end{array}$ & $\begin{array}{l}22913 \\
(50.5)\end{array}$ & $\begin{array}{l}20586 \\
(54.2)\end{array}$ & $\begin{array}{l}17948 \\
(53.8)\end{array}$ & $\begin{array}{l}19352 \\
(51.2)\end{array}$ & $\begin{array}{l}12826 \\
(52.6)\end{array}$ & $\begin{array}{l}41013 \\
(53.0)\end{array}$ & $\begin{array}{l}26920 \\
(52.9)\end{array}$ & $\begin{array}{l}23136 \\
(52.2)\end{array}$ \\
\hline $\operatorname{Cost} B_{1}$ & 20312 & 17320 & 24072 & 21744 & 19107 & 20511 & 13985 & 42172 & 28079 & 24295 \\
\hline $\operatorname{Cost} B_{2}$ & 34081 & 30435 & 40993 & 33833 & 29426 & 33754 & 20630 & 69255 & 44943 & 39348 \\
\hline Cost $C_{1}$ & 20960 & 17910 & 24291 & 22419 & 19974 & 21111 & 15518 & 43147 & 29332 & 25222 \\
\hline Cost $\mathrm{C}_{2}$ & 34729 & 31025 & 41212 & 34508 & 30293 & 34353 & 22163 & 70230 & 46197 & 40275 \\
\hline Cost $\mathrm{C}_{3}$ & 38202 & 34127 & 45334 & 37959 & 33322 & 37789 & 24379 & 77253 & 50816 & 44302 \\
\hline
\end{tabular}

Figures in bracket shows the percentage to $\operatorname{cost} \mathrm{C}_{3}$ 
Table.6 Profitability of selected crops under farming system

\begin{tabular}{|c|c|c|c|c|c|c|c|c|c|c|}
\hline \multirow[t]{2}{*}{ Particulars } & \multicolumn{6}{|c|}{ Crops } & \multicolumn{3}{|c|}{ Horticulture } & \multirow{2}{*}{$\begin{array}{l}\text { Over all } \\
\text { average }\end{array}$} \\
\hline & Paddy & Maize & Soybean & Wheat & Gram & Average & Marigold & Cabbage & Average & \\
\hline \multicolumn{11}{|l|}{ Small size group } \\
\hline Gross income & 79425 & 77187 & 95745 & 70750 & 65586 & 77738 & 41880 & 160000 & 100940 & 89339 \\
\hline Net farm income & 43286 & 46395 & 56325 & 38185 & 32832 & 43405 & 17222 & 83149 & 50186 & 46795 \\
\hline Farm business income & 63487 & 65969 & 80520 & 57205 & 52214 & 63879 & 30618 & 129631 & 80124 & 72002 \\
\hline Family labour income & 48822 & 51676 & 63134 & 43985 & 39855 & 49494 & 22209 & 101536 & 61872 & 55683 \\
\hline Benefit cost ratio & 2.19 & 2.50 & 2.42 & 2.17 & 2.00 & 2.25 & 1.69 & 2.08 & 1.88 & 2.06 \\
\hline Cost of production per quintal & 778 & 508 & 1288 & 656 & 1223 & 890 & 883 & 240 & 561 & 726 \\
\hline \multicolumn{11}{|l|}{ Medium size group } \\
\hline Gross income & 85687 & 77731 & 93080 & 66468 & 70609 & 78715 & 45930 & 168000 & 106965 & 92840 \\
\hline Net farm income & 47326 & 43913 & 49474 & 26005 & 35168 & 40377 & 19091 & 91684 & 55388 & 47883 \\
\hline Farm business income & 66985 & 61928 & 70627 & 43515 & 52456 & 59102 & 32447 & 128939 & 80693 & 69897 \\
\hline Family labour income & 51339 & 47608 & 53749 & 31072 & 39324 & 44618 & 23427 & 99574 & 61501 & 53059 \\
\hline Benefit cost ratio & 2.23 & 2.29 & 2.13 & 1.64 & 1.99 & 2.05 & 1.71 & 2.20 & 1.95 & 2.00 \\
\hline Cost of production per quintal & 764 & 567 & 1472 & 888 & 1229 & 984 & 876 & 227 & 551 & 768 \\
\hline \multicolumn{11}{|l|}{ Large size group } \\
\hline Gross income & 82612 & 78688 & 101530 & 72531 & 61914 & 79455 & 39870 & 162500 & 101185 & 90320 \\
\hline Net farm income & 44409 & 44560 & 56196 & 34571 & 28591 & 41666 & 15490 & 85246 & 50368 & 46017 \\
\hline Farm business income & 63458 & 62526 & 78616 & 51944 & 43965 & 60102 & 27043 & 121486 & 74264 & 67183 \\
\hline Family labour income & 48531 & 48253 & 60536 & 38697 & 32487 & 45701 & 19239 & 93244 & 56241 & 50971 \\
\hline Benefit cost ratio & 2.16 & 2.30 & 2.23 & 1.91 & 1.85 & 2.09 & 1.63 & 2.10 & 1.86 & 1.97 \\
\hline Cost of production per quintal & 792 & 565 & 1401 & 755 & 1322 & 967 & 917 & 237 & 577 & 772 \\
\hline
\end{tabular}


Table.7 Average profitability of selected crops under farming system

Unit: Rs.

\begin{tabular}{|c|c|c|c|c|c|c|c|c|c|c|c|c|}
\hline \multirow[t]{2}{*}{ Particulars } & \multicolumn{4}{|c|}{ Small farmer } & \multicolumn{4}{|c|}{ Medium farmer } & \multicolumn{4}{|c|}{ Large farmer } \\
\hline & Crops & Horticulture & Dairy & Overall & Crops & Horticulture & Dairy & Overall & Crops & Horticulture & Dairy & Overall \\
\hline $\begin{array}{l}\text { Gross } \\
\text { expenses }\end{array}$ & 34333 & 50754 & 26730 & 37272 & 38337 & 51576 & 26835 & 38916 & 37789 & 50816 & 27642 & 38749 \\
\hline $\begin{array}{l}\text { Gross } \\
\text { income }\end{array}$ & 77738 & 100940 & 69662 & 82780 & 78715 & 106965 & 71326 & 85668 & 79455 & 101185 & 67422 & 82687 \\
\hline $\begin{array}{l}\text { Net farm } \\
\text { income }\end{array}$ & 43405 & 50186 & - & 46795 & 40377 & 55388 & - & 47882 & 41666 & 50368 & - & 46017 \\
\hline $\begin{array}{l}\text { Average net } \\
\text { profit per } \\
\text { annum }\end{array}$ & - & - & 42931 & 42931 & - & - & 44490 & 44490 & - & - & 39780 & 39780 \\
\hline $\begin{array}{l}\text { Farm } \\
\text { business } \\
\text { income }\end{array}$ & 63879 & 80124 & - & 72002 & 59102 & 80693 & - & 69897 & 60102 & 74264 & - & 67183 \\
\hline $\begin{array}{l}\text { Family } \\
\text { labour } \\
\text { income }\end{array}$ & 49494 & 61872 & - & 55683 & 44618 & 61501 & - & 53059 & 45701 & 56241 & - & 50971 \\
\hline $\begin{array}{l}\text { Benefit cost } \\
\text { ratio }\end{array}$ & 2.25 & 1.88 & 2.60 & 2.24 & 2.05 & 1.95 & 2.65 & 2.21 & 2.09 & 1.86 & 2.43 & 2.12 \\
\hline $\begin{array}{l}\text { Cost of } \\
\text { production } \\
\text { per quintal }\end{array}$ & 890 & 561 & - & 725 & 984 & 551 & - & 767 & 967 & 577 & - & 772 \\
\hline $\begin{array}{l}\text { Cost of } \\
\text { production } \\
\text { per liter }\end{array}$ & - & - & 9.8 & 9.8 & - & - & 9.7 & 9.7 & - & - & 10.5 & 10.5 \\
\hline
\end{tabular}

Crop, Horticulture $=$ Rs. per ha, Dairy = Rs. per annum 
Table.8 Average net profit from diversification farming system

\begin{tabular}{|c|c|c|c|c|}
\hline Particulars & Small & Medium & Large & Overall \\
\hline Crop & 43405 & 40377 & 41666 & $\mathbf{4 1 8 1 6}$ \\
\hline Horticulture & 50186 & 55388 & 50368 & $\mathbf{5 1 9 8 0}$ \\
\hline Dairy & 42931 & 44490 & 39780 & $\mathbf{4 2 4 0 0}$ \\
\hline Total & $\mathbf{1 3 6 5 2 2}$ & $\mathbf{1 4 0 2 5 5}$ & $\mathbf{1 3 1 8 1 4}$ & $\mathbf{1 3 6 1 9 6}$ \\
\hline
\end{tabular}

Crop, Horticulture $=$ Rs. per ha, Dairy $=$ Rs. per annum

\section{Gross income from farming system}

To estimate the gross income, quantity of main product, by product and its value are required. Details about productivity and gross income of selected crops under farming system are shown in Table 5. Over all the highest productivity was found in Maize on crop groups and Cabbage in horticulture crop groups. The level of productivity of Paddy and Wheat was observed near about at par. The maximum gross income was obtained from Cabbage followed by Maize, Wheat, Paddy, Soybean, Marigold and Gram. It was found to be Rs. 82575, 77869, 96785, 69916, 66035, 42560 and 163500 for Paddy, Maize, Soybean, Wheat, Gram, Marigold and Cabbage respectively. The variation in gross income in different crops was observed in all the size groups due to price and level of production of different crops in the study area.

\section{Profit from farming system}

Profit is expressed in this analysis in three forms i.e. net, farm business and family labour income. The details about estimation of income of different size group under farming system have been given in Table 6 . Under crop group, the average net, farm business, and family labour income per hectare were observed to be Rs. 43405, 63879 and 49494 respectively. The gross income was found to be Rs. 79425, 77187, 95745, 70750, 65586, 41880 and 160000 for Paddy, Maize, Soybean, Wheat, Gram, Marigold and
Cabbage respectively. Under crop group, the net income was found highest in Soybean crop followed by Paddy, Maize, Wheat and Gram. While in horticulture crop, the net income was more in Cabbage than Marigold and it was 79 per cent higher than Marigold. The net farm income was observed to be Rs. 43286, 46395, 56325, 38185, 32832, 17222 and 83149 for Paddy, Maize, Soybean, Wheat, Gram, Marigold and Cabbage respectively.

The result of B.C. ratio shows that raising all the selected crops are profitable but the variation among the crops was observed. As far as cost of production per quintal was concerned, its shows that more fund are required in Soybean (Rs.1288) than the other crops under small size group. The pattern of net, farm business, family labour income, cost of production per quintal and B.C. ratio was near about same but the variation in amount was observed among the size groups. Over all it could be concluded that the highest net farm income was observed in Soybean in all the size group and also found that the net farm income increases as size group increased.

\section{Average profitability under farming system}

The average profitability of different size groups under farming system is given in Table 7. It revealed from the table that net farm income was found more in horticulture group then crop group and dairy enterprise. The farm business income and family labour 
income was also observed more in horticulture crop than crop group. Regarding cost of production per quintal, it was more in crop group then the horticulture crop it may be due to more productivity in horticulture crop. The average net farm income per hectare was observed to be Rs. 46795, 47882 and 46017 for small, medium and large size group respectively. Dairy enterprise was also found profitable enterprise in the farming system. On an average net profit per annum of dairy were observed to be Rs. 42931, 44490 and 39780 under small, medium and large size group respectively. Over all it could be concluded that farmers of different size groups i.e. small, medium and large adopted farming system which included three components i.e. crop, horticulture and dairy enterprise and this farming system was shows profitable business in the study area.

\section{Average Net profit from diversification farming system}

The detail about estimation of expenses and income of selected farming system was work out and discussed in the previous section. The average net profit under selected farming system are given in Table 8. It is revealed from the table that on an average net profit was observed to be under different size groups of farming system, the highest net profit was received from horticulture then other components. It was found Rs. 41816, Rs. 51980 and Rs. 42400 for crop, horticulture and dairy per annum respectively. Over all it could be concluded that the highest net income was received from diversification farming system.

In Satpura Plateau Region, it was observed that the farming systems followed by the farmers are of varied nature. Among the diversification farming system i.e. crop + horticulture + dairy enterprise was found most profitable in the study area. The farming system a long term basis can be sustainable when the reasonable balance between crop, horticulture and livestock enterprise would be maintained. Although majority of farmers keep milch animal for household consumption (milk) purpose but if number of milch animal increased then farmers can sell milk to enhance their family income. In view of this it is necessary to motivate the farmers to adopt livestock based farming system suitable to Satpura Plateau Region for proper utilization of resources. There is ample scope for increasing the farm income if farmers adopted diversification farming system in the study area.

\section{References}

Bazaz Naseer Hussain and Haq Imtiyaz ul. 2013. Agricultural Diversification and Self-Sufficiency in Jammu \& Kashmir. Agricultural Economics Research Review, Vol. 26, pp. 252.

Birthal P.S., Jha A.K., Joshi P.K. and Singh D.K. 2006. Agricultural diversification in North Eastern Region of India implication for growth and equity. Indian Journal of Agriculture Economics, Vol. 61, No. 3. pp. 328339.

Hasan Rooba, Singh H. P., Singh Rakesh and Khan Diwan Nayeer. 2013. Pattern of Crop Diversification and Land Use in Uttar Pradesh. Agricultural Economic Research Review, Vol. 26, pp. 251.

Luhach V.P., Khatkar R.K. and Deswal Kuldeep. 2007. Diversification towards commercial farming - A success story. Agricultural Economics Research Review, Vol. 20, pp. 590.

Mittal Surabhi, Aryal Jeetendra, Mehar Mamt a and Hariharan Vinod. 2013. Trends in Crop Diversification by Agroecological Zones of India. Agricultural Economics Research Review, Vol. 26, pp. 246. 
Rajiv Sharma. 2007. Agricultural Development and Crop diversification in Jammu and Kashmir: A district level study patterns, processes and determinants. A receive of development and change vol. XII No.2 July- Dec. 2007.

Roy Tuhin Narayan. 2013. Value-added Diversified Floriculture - Scope of New Products for Higher Returns to Small and Marginal Floricultural Farmers of West Bengal. Agricultural Economics Research Review, Vol. 26, pp. 249.

Shinde H.R., Suryawanshi R.R., Gawade B.B. and Ratnparkhe A.N. 2013. Extent of Crop Diversification in Maharashtra: A Region wise Analysis. Agricultural Economics Research Review, Vol. 26, pp. 260.

Singh Gomatee, Ashraf S. and Waseem A. 2013. Crop Diversification - A Desired Strategy towards Sustainable Development and Economic Upliftment of Farmers. Agricultural Economics
Research Review, Vol.26, pp. 248

Singh S.P., Gangwar B. and Singh M.P. 2007. Farming systems diversification: A study on marginal holders in western Uttar Pradesh. Agricultural Economics Research Review, Vol. 20, pp. 589.

Singh S.P., Gangwar B. and Singh M.P. 2009. Economics of Farming Systems in Uttar Pradesh. Agricultural Economics Research Review, Vol. 22, pp. 129-138.

Suresh A., Gupta D.C., Mann J.S. and Singh V.K. 2006. Diversification of crop and livestock sector for rural livelihood in drought-prone areas: Analysis of pattern, determinants and impact on resource utilization in Rajasthan. Agricultural Economics Research Review, Vol. 19, pp. 166.

Torane, S.R. Naik, B.K. Kulkarni, V.S. and Talathi, J.M. 2011. Farming Systems Diversification in North Konkan Region of Maharashtra - An Economic Analysis. Agricultural Economics Research Review, Vol. 24, pp. 91-98.

\section{How to cite this article:}

Sangeeta Mawase, Sunil Kumar Mawase, Anil Kumar Rai and Jitendra Patidar. 2018. A study on Economics Analysis of Diversification Farming System in Satpura Plateau Region of Madhya Pradesh, India. Int.J.Curr.Microbiol.App.Sci. 7(02): 2422-2432. doi: https://doi.org/10.20546/ijcmas.2018.702.295 